\title{
Developing tomorrow's managers today: An examination of superior/subordinate developmental relationships
}

\author{
E.D. Schmikl \\ School of Business Leadership, University of South Africa, Pretoria
}

\begin{abstract}
Although the Mentorship concept has been around for many centuries it is being examined with renewed interest by organizational development and human resources specialists. Researchers have found that organizations that are characterized by excellence have policies that promote a corporate organizational culture in which management makes a conscious effort to develop young men and women with leadership talent. The conscious attempt by superiors to grow one or more subordinates results from the fact that two-thirds of outstanding successful executives claimed to have had mentors in their careers. Superior-subordinate developmental relationships do not always suc. ceed. Some relationships blossom, others break down. and many never even develop at all. Some studies reveal that there are good and poor mentors and special kinds of subordinates. These studies focus on the characteristics of the mentor and the protégé where developmental rela tionships have blossomed and also failed. It is furthermore suggested that where mentor-protege relationships have blossomed that this may be due to a supportive organizational culture and the fact that superiors and their subordinates had matching interactive styles that promoted interaction in their interpersonal relationships. The latter has been illustrated from managerial action profiling research. More research is re quired to establish the important link between the characteristics of ef. fective superiors and subordinates, organizational culture, and interpersonal interaction styles within superior-subordinate developmental relationships. It is argued that the effective management of superior. subordinate developmental relationships within organizations is critical if organizations are to remain productive and profitable, and survive the challenges of the next two decades.

S. Afr. J. Bus. Mgmt. 1984. 15:109-115
\end{abstract}

Alhoewel die Mentor-begrip reeds vir eeue bestaan, word daar opnuut daarna gekyk deur deskundiges op die gebied van organisasie-ontwikkeling en die bestuur van menslike hulpbronne. Navorsers het bevind dat ondernemings wat gekenmerk word deur hul uitmuntendheid ' $n$ beleid volg wat die onderneming se korporatiewe kultuur bevorder. In dié klimaat word die bestuur aangemoedig om jong mans en vrouens wat leierskapspotensiaal toon te ontwikkel. Die doelbewuste strewe na die ontwikkeling van ondergeskiktes het ontstaan uit die feit dat tweederdes van hoogs-suksesvolle bestuurders beweer het dat hul sukses te danke is aan die feit dat hulle mentors in hul loopbane gehad het. Mentor-protégé-verhoudings slaag nie altyd nie. Sekere verhoudings werk goed, andere verbrokkel, en in baie gevalle ontstaan daar nie eers ' $n$ verhouding nie. Sommige studies het ook getoon dat daar goeie en swak mentors sowel as ondergeskiktes is. Hierdie studies werp lig op die eienskappe van mentors en hul protégés waar ontwikkelings-verhoudings goed verloop het of verbrokkel het. Daar word verder beweer dat waar mentor-protégé-verhoudings vrug afwerp dit te danke is aan ' $n$ ondersteunende organisasie-kultuur sowel as interpersoonlike verhoudingstyle wat tydens interaksie harmoniseer en interaksie tussen twee partye bevorder. Laasgenoemde word geillustreer deur navorsing op die gebied van bestuursaksie-profilering. Meer navorsing word benodig om die belangrike verband tussen die eienskappe van bekwame bestuurders en hul ondergeskiktes, organisasiekultuur, asook interpersoonlike interaksiestyle in meerdere-ondergeskikte ontwikkelings-verhoudings vas te stel. Dit word beweer dat die doeltreffende bestuur van ontwikkelingsverhoudings tussen bestuurders en hul ondergeskiktes in ondernemings ' $n$ kritiese faktor sal wees indien ondernemings binne die volgende twee dekades produktief en winsgewend wil bly.

S.Afr. Tydskr. Bedryfsl. 1984, 15:109-115

E.D. Schmik!

School of Business Leadership, University of South Africa

P.O. Box 392, Pretoria 0001, Republic of South Africa

Accepted March 1984

\section{Introduction}

Researchers and human resource directors are starting to pay increased attention to the Mentorship concept as a career and development tool and the role of corporate management in creating organizational culture. Although the former concept has been around for some years, the successful implementation of the mentor process within the organization culture has not been fully understood. A number of studies have revealed that nearly two-thirds of outstanding successful executives had mentors. In fact, numerous successful executives concur that a mentor is necessary for most young managers to achieve success (Allen, 1980; Baird \& Kram, 1983; Collins \& Scott, 1978; Dalton, Thompson \& Price, 1977; Hunt \& Michael, 1983). Organizations that are characterized by excellence tend to be placing strong emphasis on growing their managerial talent (Peters \& Waterman, 1982). Having examined a number of organizations that ranked amongst the leaders, the two researchers found that within these organizations topmanagement has succeeded in creating an organizational culture that fosters and rewards the kind of managerial and employee behaviour that ensures that these organizations are productive, profitable, and remain leaders in their field. A major characteristic amongst excellent organizations is that they achieve high standards of productivity through people by showing respect for individuals and treating them as adults, - 'they live their commitment to people, as they also do their preference for action' (p. 16).

It is also known fact that there are good and bad mentors and that in many organizations world-wide the mentor process is not being consciously applied as a management development tool. Has this perhaps something to do with organizational culture? Furthermore, both researchers and human resource directors are attempting to find answers to the reasons why some mentor-protégé relationships blossom and others break down (Nasser \& Buitendag, 1984). Is the clue to the latter not also to be found in the organizational culture (Schein, 1983), or is this perhaps a further problem of unsuccessfully identifying and matching interpersonal relationship styles? (Lamb, 1979; Ramsden, 1973; Moore, 1982). Lastly, it can be questioned whether every manager can be a successful mentor for a young subordinate with potential within his/her own functional department? Matters become even more complex when the impact of mobility influences and career patterns of aspiring young managers are taken into account (Veiga, 1981, 1983), as well as the issue of women protégé's not necessarily identifying with male mentors (Bowen \& Zollinger, 1980; Sheehy, 1976). 


\section{What is a mentor?}

Mentors are defined as persons who have some standing, status and position within the organization, who identify subordinates (protégés) with potential leadership ability to become competent successful managers. They furthermore influence the promotional decisions of such subordinates in significant ways whilst coaching and devloping them over a period of time (Clawson, 1982; Hunt \& Michael, 1983; Taylor, 1980; Stumpf \& London, 1981).

In South Africa, as in the United States of America, the business ethic of the manager being responsible for developing talented subordinates is becoming gradually entrenched. There is evidence that one international banking organization is, as from this year, also commencing to assess managers on the amount of time and effort that they individually invest in developing and growing the young management talent under their supervision. Research studies reveal that mentors are seen as crucial tools for training and promoting career success for both males (Levinson, Darrow, Klein, Levinson \& McKee, 1978) and females (Adams, 1979; Scarf, 1980) and that the male model of mentorship does not appear to be totally applicable to females. There furthermore appears to be a scarcity of female mentors in the traditionally male-dominated organizational environment (Fitt \& Newton, 1979; Bowen \& Zollinger, 1980). Also, most of the research tends to focus predominantly on the sex variable (male/female). As regards South Africa in particular, there is need to examine more closely the race variable in conjunction with the sex variable as a lot can be learned with regard to the painstakingly slow process of advancing Blacks into the managerial ranks (Nasser \& Buitendag, 1984).

Mentor-protégé dyadic relations could exist between peers on the same level within organizations or between boss and subordinate. It would not be uncommon to find individuals who have helped either a peer or a subordinate to grow and to develop and now find themselves having such a person as their boss. Whether a mentor must always be older than the protégé is debatable despite the fact that Kram (1980) and Levinson et al. (1978) tended to find this characteristic in most instances of their research.

\section{Mentor-protégé relationship stages and specific characteristlcs}

Researchers are of the opinion that mentor-protégé relationships advance through various stages (Baird \& Kram, 1983; Levinson et al. 1978). Their arguments are advanced by drawing on the work of McClelland (1975) regarding individual power needs and Erikson's eight ages of man (Eikind, 1970). McClelland (1975) claims that power is the great motivator and suggests that there are four stages in an individual's need for power:

(a) the situation in which aspiring young subordinates with potential (potential protégés) seek more powerful individuals (mentors) within their organization (i.e., incorporation of power from others);

(b) the development of independent power as one grows;

(c) exercising and experiencing power as an impact on others whilst helping them, and

(d) deriving power from a higher authority.

For mentor-portégé reiationships to function effectively it is important that parties in the dyadic relationship have spocific attitudes about their relationship, that they define their role expectations, that they develop trust and openness towards one another, that they have frequent communication, and that protégés accept their mentors' power and influence over them. MacGregor (1960: 199) noted that . . . 'Every encounter between a superior and a subordinate involves learning of some kind for the subordinate'.

Researching superior-subordinate relationships in managerial development Clawson (1979) found the characteristics of effective superiors from whom subordinates learned a lot to be as follows: (Table 1).

\section{Table 1 Characteristics of effective superiors}

\section{Psychological predispositions}

I am people oriented

I tend to be even-tempered

I have a high tolerance for ambiguity

$I$ value working at and advancing at this

company

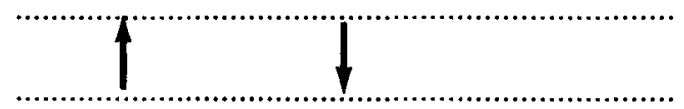

\section{Perceptions}

Perceptions of others

I respect my subordinate's intelligence

I like my subordinates

Perceptions about self

I am a teacher

I should be an example

I should direct my subordinate's activities

I should give subordinates clear feedback

I should instruct my subordinates

I should not criticize too much

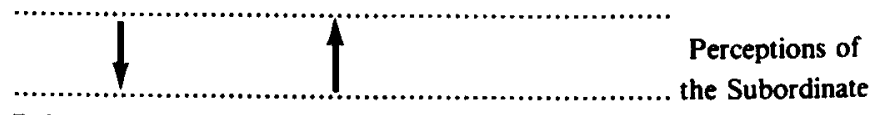

Behaviour

I take time to understand my subordinates by

Strolling the Office

Keeping an open door policy

I have an informal interpersonal style

I listen with empathy

I try to give new perspectives by:

Sharing information

Setting high but appropriate standards

Maintaining Professional Distance

Focussing on organizational learning

Giving clear feedback

Being optimally involved

I sponsor my subordinates to senior management

Equally it was found (Clawson, 1979) that the perceptions of subordinates who had claimed that they had learned a lot from their superior were as follows: (Table 2).

When examining Clawson's findings it would appear that superiors and subordinates can be differentiated into two groups and that only those who displayed the above characteristics could be classified as effective mentors and protégés. These research findings clearly indicate that not everyone can be a mentor nor is every subordinate necessarily a potential protégé. This now poses a dilemma for top management of organizations who as a general policy would like to encourage 
Table 2 Characteristics of subordinates who learned more

\section{Psychological predispositions}

I am more relationship oriented

I am marginally more independent

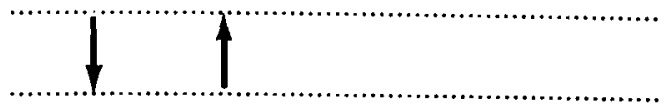

\section{Perceptions}

Perceptions of others

I respect my Boss

I like my Boss

I perceive that my Boss is interested in me

I perceive little tension in our relationship

I perceive my assignments to be relevant

Perceptions of self

I perceive my role as that of a learner

Perceptions of Boss

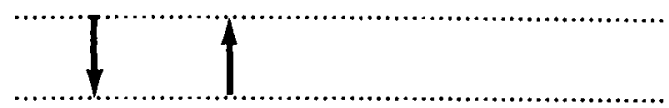

\section{Behaviour}

I respond enthusiastically

I adapt to my boss' assignments more of their managers down the line to grow and to develop the organization's young men and women with potential. If every superior cannot be an effective mentor, what then can organizations do to accelerate the management development process? Examining the mentor role it would appear that a common skill that could be taught to all managers would be how to effectively coach subordinates. In order to be an effective coach managers would have to learn coaching skills and also how people learn, and then effectively apply these skills and principles of learning in their mentor-protégé relationship with their subordinates. Even this could pose problems and more research would be required to examine the effects of such a process more closely. Apart from the different psychological predispositions, perceptions and behaviour that exist amongst effectve and ineffective superiors and subordinates, there also appears to be the problem of organization culture that does not provide impetus to accelerating or encouraging the promotion and cultivation of effective mentor-protégé relationships as a vital process ensuring that organization leadership needs of the future are being adequately met (Nasser \& Buitendag, 1984).

\section{What is organizational culture?}

Schein (1983) describes organization culture as the pattern of the basic assumptions that corporate management

‘. has invented, discovered or developed in learning

to cope with its problems of external adaptation and internal integration - a pattern of assumptions that has worked well enough to be considered valid and therefore to be taught to new organizational members as the correct way to perceive, think, feel and behave in relation to those problems' (p. 14).

An example would be:

... the only way to manage this growing business successfully is to supervise every detail on a daily basis, and if necessary, to hire competent people from outside. Lets not waste time on all the training . . .

Schein (1983) explores the difficulties managers have in developing shared assumptions about the realities of the world in which they exist and how entrepreneur/founder/owners differ from professional managers in the kind of organizational cultures they create. If for instance Black advancement efforts within organizations in South Africa are to gain real impetus, top management must re-think its policies and ensure that the organizational culture is supportive of their policies. If the policies do not embed the culture corporate management wants manifest, management behaviour is likely to be in conflict with what corporate management desires to achieve and any change process is likely to be painfully slow and costly.

\section{Developmental relationships}

Most developmental relationships tend to be dyadic and can therefore be classed as an interpersonal relationship. Since mentor-protégé roles are products of an interpersonal relationship, Clawson (1979) argues that they cannot be legislated or structurally created. He however claims that although much can be done to foster their development from an organizational viewpoint, in the end protégé-mentor relationships

$\therefore$. . are the result of the interpersonal evaluations of two individuals who see opportunities in their relation-

ship to fulfill very personal objectives' (p. 8).

For mentors it is rewarding to express their inner motivations to develop potential young individuals and for protégés it is an opportunity to have support, guidance, advice, and friendship as they develop and grow in professional competence. Clawson (1979) found that effective developmental relationships were characterized by the factors shown in Table 3.

As can be seen from Clawson's findings, the effective mentor-protégé developmental relationships tend to be based on a high level of interaction, - that is, individuals meet frequently and the relationship tends to be informal. In order to fully understand why mentor-protégé relationships are difficult to form and can take up to six months or more to become established (Kram, 1980) or even break up, it is important to focus attention on the characteristics of an interpersonal relationship.

Table 3 Characteristics of effective developmental relationships

\section{Psychological predispositions}

The boss has a higher task orientation than the subordinate

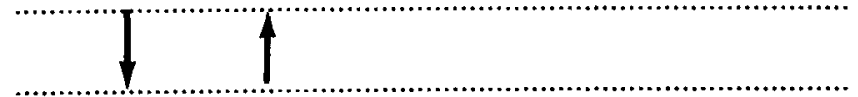

\section{Perceptions}

The other person is interested in me

There is a lot of praise in our relationship

We have complementary roles

(The boss teaches, and the subordinate learns)

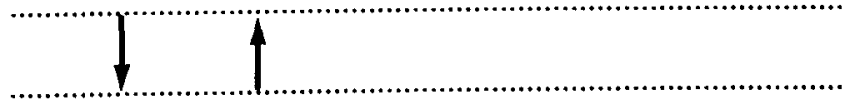

Behaviour

We meet almost twice a day.

We have more frequent 'perspective' discussions

Our relationship is informal 


\section{What is an interpersonal relationship?}

In any interpersonal relationship people interact through communication. Interpersonal communications are characterized by four interacting patterns. A person can either be sharing, private, versatile or neutral. Sharing individuals invite others to join in in sharing their mutual processes of investigating and exploring, building resolve and stating beliefs, evaluating needs and priorities, taking decisions and organizing and directing others, and anticipating the consequences of their actions and events. Private individuals switch the sharing process off whilst versatile individuals alternate between being private and sharing. Neutral individuals require to be catalysed by others.

When considering the comment examples from Bill and Sue as provided by Baird and Kram (1983: 46) relating to superiorsubordinate relationships it would appear that Bill's superior may be versatile with a tendency towards privateness and Sue's superior may be private or neutral in their interaction with others. The examples of their remarks about their superiors are provided below:

'I don't know what's wrong with my boss. When we came to the data center together three years ago, we knew our job was to decentralize and over a two-year period put ourselves out of a job. We used to work well together. We've done what we came to do, and we should be looking for new jobs. I have been thinking about switching from data processing to human resources. Trouble is, my boss is no help at all. I can't even get any leads from him or help in deciding what to do.'

- Bill

'When I joined the organization three months ago I had high hopes. I liked the group I'd be working with and I particularly liked the person I would be reporting to directly. He had been on the job only three months and had lots of enthusiasm and drive. He seemed like a fast-rising star that it would be good to link up with. But nothing has worked out. He just doesn't seem to have the time or interest to help me get established and learn this job.'

- Sue

The pioneering work done by Lamb and Watson (1979), More (1982), and Ramsden (1973) significantly contributes towards understanding some of the problems related to interpersonal interaction in developmental relationships. Lamb's interest in human behaviour with specific reference to what motivates people to act in various but distinct ways, was sparked off by his studies under Laban during 1946 - 1953. Lamb developed two frameworks of management initiative which reflect the managers'

(i) motivation to act in a unique and preferred manner when initiating the problem-solving and decision-making process in action; and

(ii) the motivation to interact in relation to others whilst being engaged in the problem-solving and decision-making process. These frameworks are reproduced in Tables 4 and 5.

Lamb's model for studying action and interaction with others is known as managerial action profiling. The action profiles of individuals reflects their 'action drives', - that is, their inbuilt energy or motivation to act in various ways. It does not reflect competence or ability. Action profiles reveal how individuals are likely to behave on the job and interact with others. Research studies on large samples of managers showed that they tended to spend more effort and time performing activities in those areas in which they had high potential
Table 4 Framework of management initiative: the motivation to act

The decision making process in action

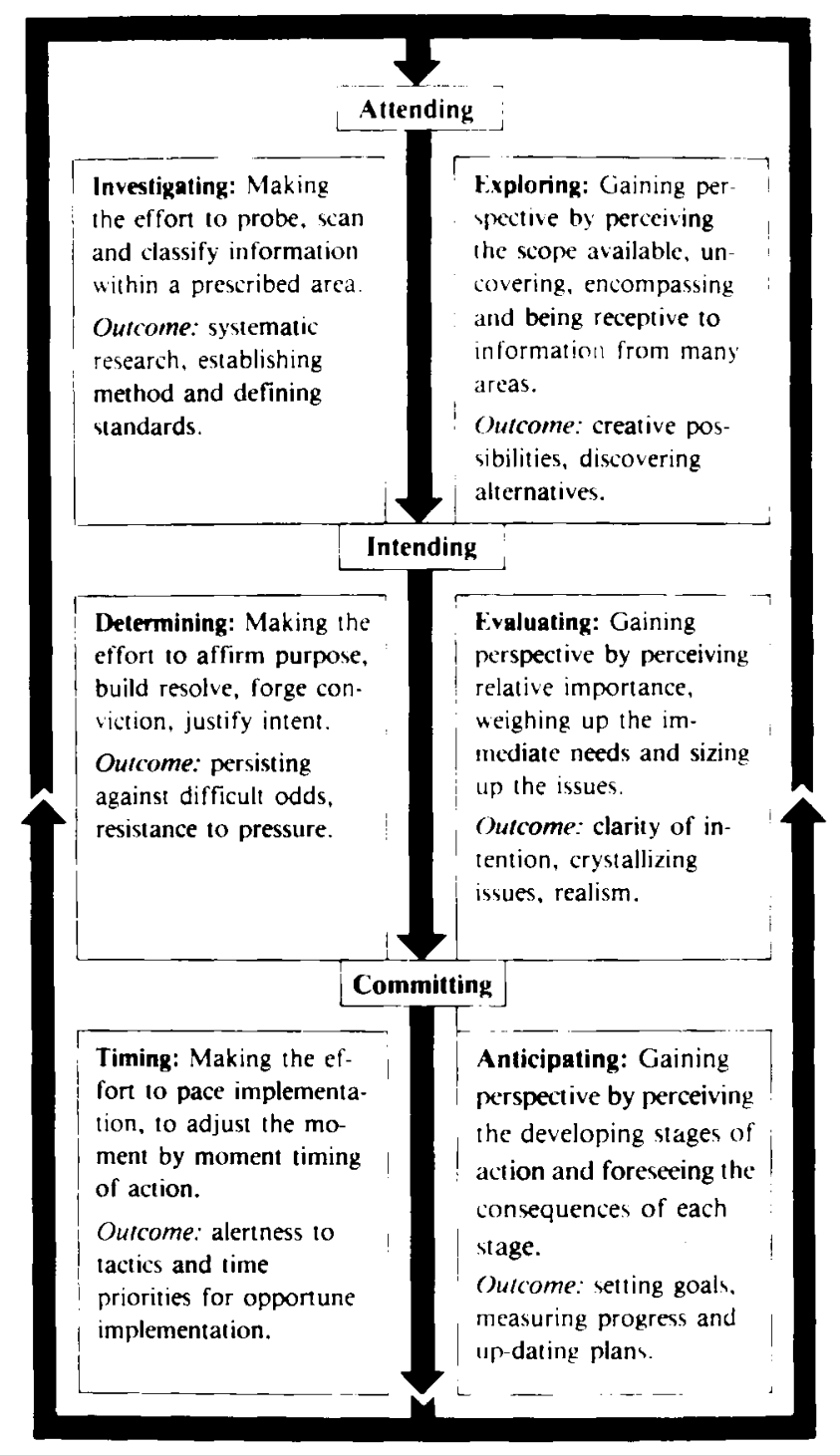

energies. Average scores of $10 \%$ or less in a profile appears to create a 'blind spot' in those persons, which despite their individual competence, they may find difficult to overcome.

To illustrate the value action profiling may provide in researching and understanding mentor-protégé relationships, an example is provided below. Example:

Considering the motivation to act

\begin{tabular}{|c|c|c|c|}
\hline & Boss & Subordinate $\mathrm{A}$ & Subordinate B \\
\hline Investigating & 21 & 12 & 23 \\
\hline \multicolumn{4}{|l|}{ Attending } \\
\hline Exploring & 16 & 13 & 18 \\
\hline Determining & 25 & 26 & 14 \\
\hline \multicolumn{4}{|l|}{ Intending } \\
\hline Evaluating & 22 & 4 & 2 \\
\hline Timing & 9 & 23 & 33 \\
\hline \multicolumn{4}{|l|}{ Committing } \\
\hline Anticipating & 7 & 22 & 10 \\
\hline Dynamism & 7 & 6 & 3 \\
\hline Adaptability & Moderate & Low & High \\
\hline Identification & High & High & High \\
\hline
\end{tabular}


Table 5 Framework of management initiative: the motivation to act

The decision making process in relation to others

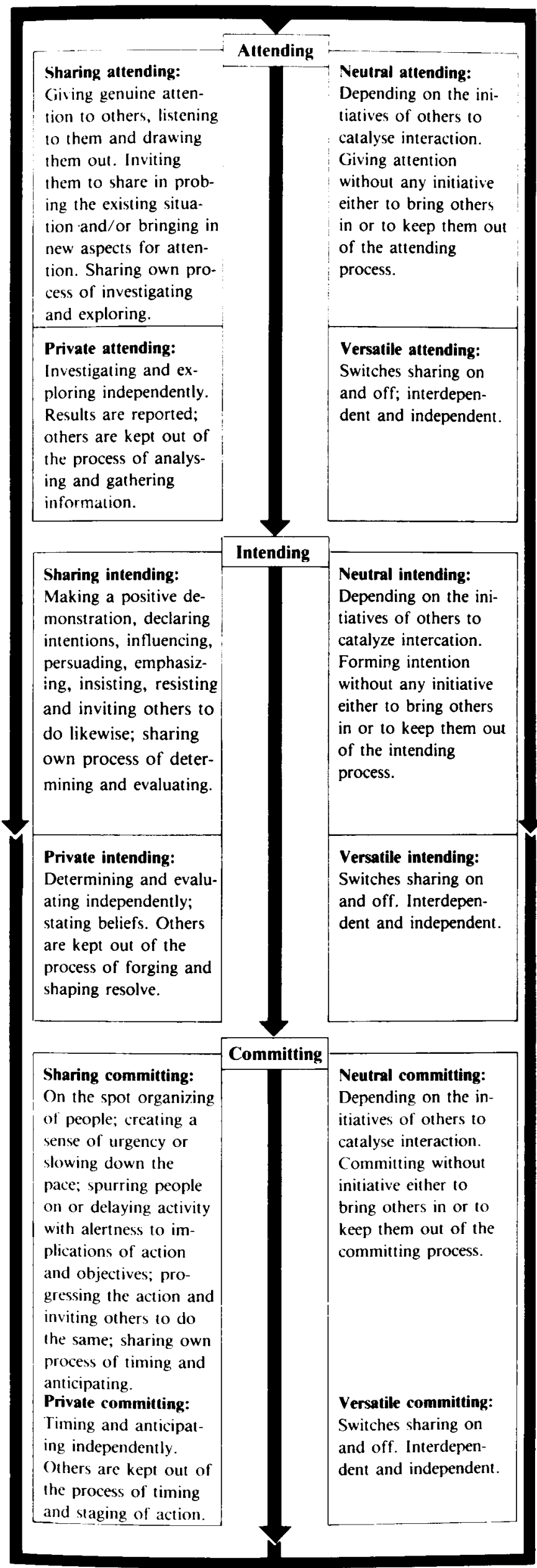

When examining the superior's and subordinate's action profiles it is important to bear in mind:

(a) that persons have a unique and individual pathway their thinking takes when they go through a problem-solving and decision-making process;

(b) that they tend to begin the problem-solving decision process in the areas where they have the highest action drive, spending on the whole, more time in these areas. They then progress on through the other areas in order of their relative magnitude in their action profile;

(c) that inherent in every persons' action profile are certain strengths and weaknesses and that all action drives, whether they be high or low, they represent both potential weaknesses and strengths.

When the superior and subordinates act within their environment, the flow of their inbuilt energy is likely to follow the undermentioned sequence:

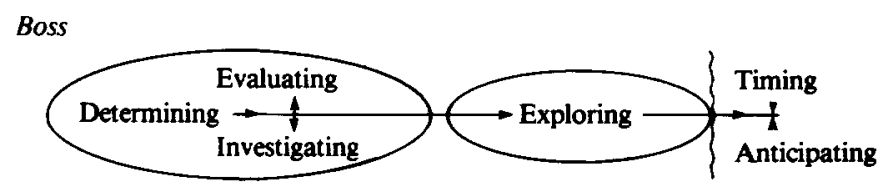

Subordinate $A$

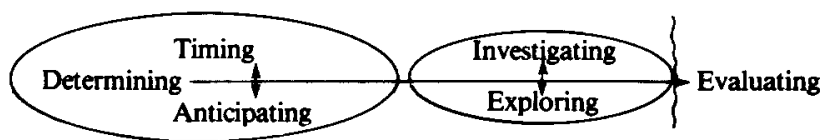

Subordinate $B$

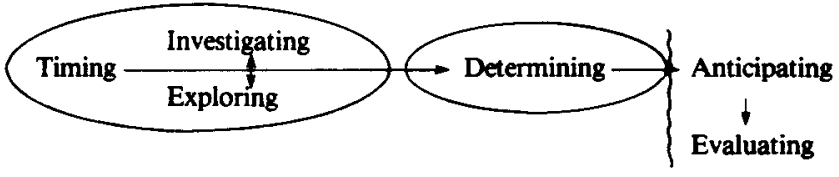

The superior can be described as an intending attender, he is a determined investigator, evaluator and explorer, but a cautious committer. When interacting with such a boss, subordinates like persons $\mathrm{A}$ and $\mathrm{B}$, may become frustrated as they have a greater drive to want to go into action and not delay.

Subordinate $\mathrm{A}$ is determined to investigate and explore trends he perceives and then wants to act. He can be labelled as a strategist (committing intender) whilst subordinate B is a committing attender, - good researcher and impulsive operator. Subordinate A could benefit by mentoring with his superior when it comes to exploring and evaluating and considering the operational practicalities of the job. He is furthermore low in adaptability and does not change easily and is likely to be criticized by his superior as being too theoretical, not following through on his actions, and failing to weigh up his priorities correctly. On the other hand the superior can benefit by sharing in his subordinates ability to anticipate and not resisting the signals for action.

Subordinate B could benefit by mentoring if he could be given help in evaluating and determining his priorities. Whether the superior is able to establish an effective mentor-protégé relationship is dependent on each individual's motivation to interact.

To illustrate this point, the same three people's profiles are reproduced together with their interaction profiles. 
Considering the Motivation to interact.

\begin{tabular}{|c|c|c|c|c|c|c|}
\hline \multirow{3}{*}{$\begin{array}{l}\text { Investigating } \\
\text { Attending } \\
\text { Exploring }\end{array}$} & \multicolumn{2}{|c|}{ Boss } & \multicolumn{2}{|c|}{ Subordinate $\mathbf{A}$} & \multicolumn{2}{|c|}{ Subordinate B } \\
\hline & 21 & $\begin{array}{l}\text { Versatile } \\
\text { interaction }\end{array}$ & 12 & $\begin{array}{l}\text { Sharing inter- } \\
\text { action }\end{array}$ & 23 & $\begin{array}{c}\text { Versatile inter- } \\
\text { action }\end{array}$ \\
\hline & 16 & & 13 & & 18 & \\
\hline $\begin{array}{l}\text { Determining } \\
\text { Intending }\end{array}$ & 25 & $\begin{array}{l}\text { Sharing } \\
\text { interaction }\end{array}$ & 26 & $\begin{array}{c}\text { Neutral } \\
\text { intercation }\end{array}$ & 14 & $\begin{array}{c}\text { Neutral } \\
\text { interaction }\end{array}$ \\
\hline Evaluating & 22 & & 4 & & 2 & \\
\hline $\begin{array}{c}\text { Timing } \\
\text { Committing }\end{array}$ & 9 & $\begin{array}{c}\text { Versatile } \\
\text { interaction }\end{array}$ & 23 & $\begin{array}{c}\text { Versatile } \\
\text { interaction }\end{array}$ & 33 & $\begin{array}{c}\text { Neutral } \\
\text { interaction }\end{array}$ \\
\hline Anticipating & 7 & & 22 & & 10 & \\
\hline Dynamism & 7 & & 6 & & 3 & \\
\hline Adaptability & Moderate & & Low & & High & \\
\hline Identification & High & & High & & High & \\
\hline
\end{tabular}

The above illustration provides ample evidence that the superior could be a good mentor. This happens also to be the case with this person who is a group managing director of a medium sized organization. He could become more effective if he had insight into his own profile and those of his subordinates. Work carried out in this organization has in fact provided him with this information. Being versatile and sharing in his interaction with others gives this superior the distinct ability to catalyse and draw out subordinates who tend to be neutral or private.

As regards subordinate $A$, if he were to mentor with his own subordinates, he could be effective in his interaction whenever he investigates and explores and commits himself to action. However, if subordinates or peers wished to know this managers' intentions, they would have to catalyse him to obtain this information. Equally his superior would have to catalyse him in the intentional phase of the decision process. As regards subordinate $B$, he is likely to be classed as a poor mentor. His subordinates are likely to feel like Sue as reported by Baird and Kram (1983). Subordinate B is a managing director of a subsidiary. It can be argued that where superiors or protégés are either neutral or private in their interaction, no effective developmental relationship is likely to emerge. The accumulated research on managerial action profiling tends to provide possible answers and insights on effective interpersonal developmental relationships and their breakdowns.

\section{Conclusions}

The effective management of superior-subordinate developmental relationships within organizations is critical if organizations are to remain productive and profitable, and survive the challenges of the next two decades. In South Africa and the developing third world nations this need is even more pertinent. Mentorship is a critical on-the-job training and development tool for career success for men and women of all races. A lot of research remains to be undertaken to bridge some of the problems and accelerate the conscious effort of the mentor process within organizations. Apart from the research issues listed by Hunt and Michael (1983), a closer look can be taken at the possibility of matching interpersonal interaction styles and ways and means of accelerating organizational culture changes that would promote increased superior/ subordinate developmental relationships.

\section{References}

Adams, J. 1979. Women on top. New York: Hawthorn.

Allen, F. 1980. Many Bosses already have decided who successors will be and why. Wall St. J. Nov. 18.

Baird, L. \& Kram, K. 1983. Career dynamics: Managing the superior/subordinate relationship. Organ. Dyn. Spring, 46-64.

Bowen, D.D. \& Zollinger, P.L. 1980. Mentoring and the careers of women managers. Paper presented at the Academy of Management Meetings, Detroit.

Clawson, J.G. 1982. Mentoring in Managerial Careers. In C. Brooklyn Derr (ed.), Work, family, and the career. New York: Praeger.

Clawson, J.G. 1979. Superior-subordinate relationships in managerial development. Unpublished doctoral dissertation, Harvard Business School.

Clawson, J.G. Mentoring in Managerial Careers. Working paper HBS, $79-81$.

Collins, E.G.C. \& Scott, P. 1978. Everyone who makes it has a mentor. Harv. Bus. Rev. July-August, 89-101.

Dalton, G.W., Thompson, P.H. \& Price, R.L. 1977. The four stages of professional careers - a new look at performance by professionals. Organ. Dyn. Summer pp. 19-42.

Elkind, E. 1970. Erik Erikson's Eight Ages of Man. The New York Times Magazine, $25-37$.

Fitt, L.W. \& Newton, D.A. Wanted: more mentors for female employees. Working paper DSWP-79-26.

Hunt, D.M. \& Michael, C. 1983. Mentorship: A career training and development tool. Acad. Mgmt. Rev. vol. 8 475-485.

Kram, K.E. 1980. Mentoring processes at work: Developmental relationships in managerial careers. Unpublished Ph.D. dissertation, Yale University.

Kram, K.E. \& Isabella, L.A. 1983. Mentoring alternatives: The role of peer relationships in career development. Paper, Boston School of Management, May.

Lamb, W. \& Watson, E. 1979. Body Code: The meaning of movement. London: Routledge \& Kegan Paul.

MacGregor, D. 1960. The human side of enterprise. New York: McGraw-Hill.

McClelland, D.C. 1975. Power: the inner experience. New York: Irvington.

Moore, Carol-Lynne. 1982. Executives in Action: a guide to balanced decision-making in management. Estover, Plymouth: MacDonald \& Evans.

Nasser, M.E. \& Buitendag, J.J. 1984. Mentoring - the key to accelerated manager development. S.A. Training Yearbook.

Peters, T.J. \& Waterman, R.H. 1982. In search of Excellence. New York: Harper \& Row.

Ramsden, P. 1973. Top team planning: A study of the power of individual motivation in management. London: Associated Business Programmes Ltd.

Scarf, M. 1980. Unfinished business: Pressure points in the lives of women. New York: Doubleay \& Co.

Sheehy, G. 1976. Passages: Predictable crises of adult life. New York: E.P. Dutton and Co.

Schein, E.H. 1983. The role of the founder in creating organizational culture. Organ. Dyn. Summer, 13-28. 
Stumpf, S.A. \& London, M. 1981. Management promotions: Individual and organizational factors influencing the decision process. Acad. Mgmt Rev. vol. 6: 539-549.

Taylor, M. 1980. Mentors: those helping hands that launch, guide careers of so many. Chicago Tribune, October 26.

Veiga, J.F. 1981. Do managers on the move get anywhere? Harv.
Bus. Rev. March - April, 1 - 9.

Veiga, J.F. 1981. Plateaued versus non-plateaued managers: Career patterns, attitudes, and path potential. Acad. Mgmt. J. vol. 24, $566-578$.

Veiga, J.F. 1983. Mobility influences during managerial career stages. Acad. Mgmt. J. vol. 26(1), 64-85. 